\title{
Structural Equation Model for the Relationship between Accounting Information System and Internal Audit Effectiveness with Moderating Effect of Experience
}

\author{
Oday Jasim Almaliki ${ }^{\mathrm{a}}$, Nor Hanani Ahamad Rapani ${ }^{\mathrm{b}}$, Azam Abdelhakeem Khalid ${ }^{\mathrm{c}}$, \\ Rasool Majid Sahaib ${ }^{\mathrm{d}}$ \\ ${ }^{a}$ Faculty of Administration and Economic, Universiti of Misan, Iraq \\ almalikiuday@yahoo.com \\ ${ }^{b}$ Faculty of Management and Economics, Universiti Pendidikan Sultan Idris, Malaysia \\ norhanani@fpe.upsi.edu.my \\ ${ }^{c}$ Faculty of Management and Economics, Universiti Pendidikan Sultan Idris, Malaysia \\ azamabdelhakeem@fpe.upsi.edu.my \\ ${ }^{d}$ Faculty of Administration and Economics, Universiti of Misan, Iraq \\ rasol@uomisan.edu.iq
}

DOI: https://doi.org/10.37134/ibej.vol12.6.2019

\begin{abstract}
Accounting information system and internal audit effectiveness assist management in making appropriate decisions. The experience of accountants and auditors may enhance decision making. Moreover, the effect of accountants' and auditors' experience on the relation between accounting information system and internal audit effectiveness was not considered in the previous studies. This research aims to develop a structural equation model for the moderating effect of experiences on the relation between accounting information system characteristics and the internal audit effectiveness in Iraqi stock exchange-traded companies. Five constructs representing the characteristics of accounting information system have been selected including integration, flexibility, reliability, relevance, and timeliness. A quantitative approach has been used to achieve the research objective. A survey was conducted on 365 respondents including accountants, auditors and managers in several companies in the Iraqi stock exchange. Statistical Package for the Social Sciences and Analysis of Moment Structure were used to analyze the data and develop the structural equation model. The research results indicated that all the selected accounting information system characteristics had significant effects on internal audit effectiveness. Moreover, experience moderated the relationships between flexibility, integration characteristics, and internal audit effectiveness. Such research findings can assist organizations in assessing and enhancing the quality of their information and the skills and knowledge of their employees, particularly their accountants and auditors.
\end{abstract}

\section{Keywords:}

Accounting information system, internal audit effectiveness, experience

\section{INTRODUCTION}

Effective internal audit supports organizations to diminish operational risks and to improve the reliability of financial reporting that helps to increase the shareholders' trust (Abbas and Iqbal, 2012). The development of internal audit (IA) in the accounting information system (AIS) helps to protect corporate assets from losses and misuse and keep the organization's financial data accuracy (Jones and Rama, 2003). Accounting represents a significant information source for decision-making and, particularly, managerial decision making is extensively approved. Many researchers (Nicolaou, 2000; McGilvray, 2008; Sri Mulyani, Manuscript received July 17, 2019; revised Oct 27, 2019; published December 27, $2019 \quad 62$ 
2009; Bazley, et al., 2014) found that good quality of the information provided by AIS helps all levels of management to make proper decisions which lead to achieving the goals of an organization. According to Soudani (2013), AISs are responsible for recording, analyzing, monitoring and evaluating companies' financial conditions. Moreover, it can enhance the control and governance processes through information and risk assessment (Tan, 2016). The experience of the accountant's staff and management is an important factor that can enable the management to make the right decisions that improve IA performance. A high level of experience of accountants and auditors indicates that the organization can perform better than others with low experience levels (Classen, et. al., 2012).

The internal audit plays a great role in evaluating and verifying the accuracy of the information, reports and financial statements generated by the AIS. Therefore, to enhance the information credibility and reliability and to ensure the organization's success and continuity, this research came to find out the impact of the AIS on the quality of internal audit in the Iraqi stock exchange-traded companies. Since these companies deal mainly with the financial information, this research investigates the effect of important quality characteristics of the AIS on the IA by considering the moderating effect of accountants' and internal auditors' experience. The researchers utilized different AIS characteristics based on their study field. Therefore, and to generalize the findings, the most frequent characteristics in the previous studies have been used in this research to measure the AIS quality.

Several authors defined effectiveness in terms of attaining the IA aims and objectives but in various manners. Arena and Azzone (2009) defined internal audit effectiveness (IAE) as "the capacity to obtain results that are consistent with targets". Since IA is one of the organization activities, then achieving IA aims are related to IAE. The IAE is defined as "the extent to which an internal audit office meets its supposed objective or the extent to which it meets the intended outcome" (Mihret and Yismaw, 2007). Abbas and Iqbal (2012) found that effective internal audit systems aid organizations to minimize operational risk and to enhance the financial reporting reliability which helps to build the trust of shareholders. In the same context, Laudon and Laudon (2004) explained that an improvement of IA effectiveness affected positively the quality and reliability of the information system. Therefore, effective IA helps to improve the evaluation of risk and enhance the risk management effectiveness (Mihret and Yismaw, 2007) and enhance control and governance processes by applying a systematic and disciplined approach to the assessment of risk and information which aid organizations to achieve its goals and objectives (Tan, 2016).

Researches investigate the impact of AIS on organization performance or organization department and activities and explore the influence of AIS on internal control. Moorthy et al. (2011) addressed the significant effect of AIS and IT in general on the effectiveness of both internal audit and internal control in organizations. Tan (2016), investigated the AIS impact on the internal auditor in Turkey. He stated that the main role of internal audit is helping organizations to reach their goals by assessing the effectiveness of risk management, control, and governance. AISs can identify, analyze, classify, assemble, record, review and report events, which help internal auditors to achieve their goals. Al-Qudah and Ahmed (2011) indicated in their study that AIS has an impact on IAE in Jordan commercial bank. In the same context, Shanti (2013) showed that the application of AIS in the Jordanian industrial sector leads to improve the effectiveness of internal auditing by increasing compliance with preset laws and policies, as well as providing necessary information in time to make decisions. Likewise, Hussein (2005) confirmed the effect of AIS on internal auditing systems. 
Accounting information must have essential characteristics to achieve its objectives such as importance, appropriateness, accuracy, credibility, timing, understanding and absorption (Abdallah, 2014). Qualitative characteristics are the characteristics of AIS which aim to increase its usefulness and understandability (Bukenya, 2014). Hiedmann et.al., (2008) indicated that integration, flexibility, accessibility, formalization and media richness are determinants of successful AIS. Romney (2009), stated that the most important characteristic of AIS reliability, efficiency, integration, and flexibility. On another side, Ong et al. (2009) and Wixom and Todd (2005), stated that good AIS are defined by achieving four dimensions: reliability, flexibility, integration, accessibility, and timeliness. Finally, Napitupulu et al. (2016) used four factors to identify good and effective AIS namely integration, reliability, flexibility and efficiency.

Experience is the collective knowledge learned by persons which helps them in taking the right decision (Vera-Munoz, Kinney Jr, \& Bonner, 2001). Experience enables individuals to have the skill and knowledge in managing their work, developing relevant information, and using proper decisions making. Experience is still in the infancy stage in business researches. High levels of experience help the management take right decisions (von den Driesch et al., 2015; Saatcioglu, et al., 2012; Vasudevan \& Chawan, 2014). Datta and Iskandar-Datta (2014) stated that that audit management experience has a major impact on organizations strategic decision. High experience has a positive impact on the development of new product and services, dynamic capabilities of companies, as well as the internal competitiveness (Saatcioglu et al., 2012; Vasudevan \& Chawan, 2014; von den Driesch et al., 2015). Auditors' good experience helps them to reduce the negative impact of errors and dereliction in the financial statements reports prepared by less experience accountants. However, previous studies did not investigate the impact of experience on the relationship between AIS and IAE. Almaliki et al. (2018) is one of the first who developed a conceptual model to clarify the relationship between AIS characteristics and IAE with experience as a moderator.

\section{CONCEPTUAL MODEL}

This research adopted with some modification of the conceptual model developed by Almaliki et al. (2018). The direct effect of AIS on IAE is eliminated since the effects of AIS characteristics are considered. The same AIS characteristics are utilized including integration, flexibility, reliability, relevance, and timeliness. The agency theory is adopted to support the developed conceptual model and the hypotheses. The agency theory discusses the relations between the owner(s) of organization and its top management (Changwony and Rotich, 2015; Adams, 1994). The management has the experience and the ability to control the accounting information and the accounting policies and estimates, which may conflict with the other stakeholders' interests. Hence to achieve the balance in this relation, there is a need to introduce a third party that is the internal auditors to monitor the whole activities of the organization (Peursem and Pumphrey, 2005). The developed conceptual model is introduced in Figure 1. The independent variables are integration, flexibility, reliability, relevance, and timeliness. The IAE is the dependent variable and the experience is the moderated variable. 


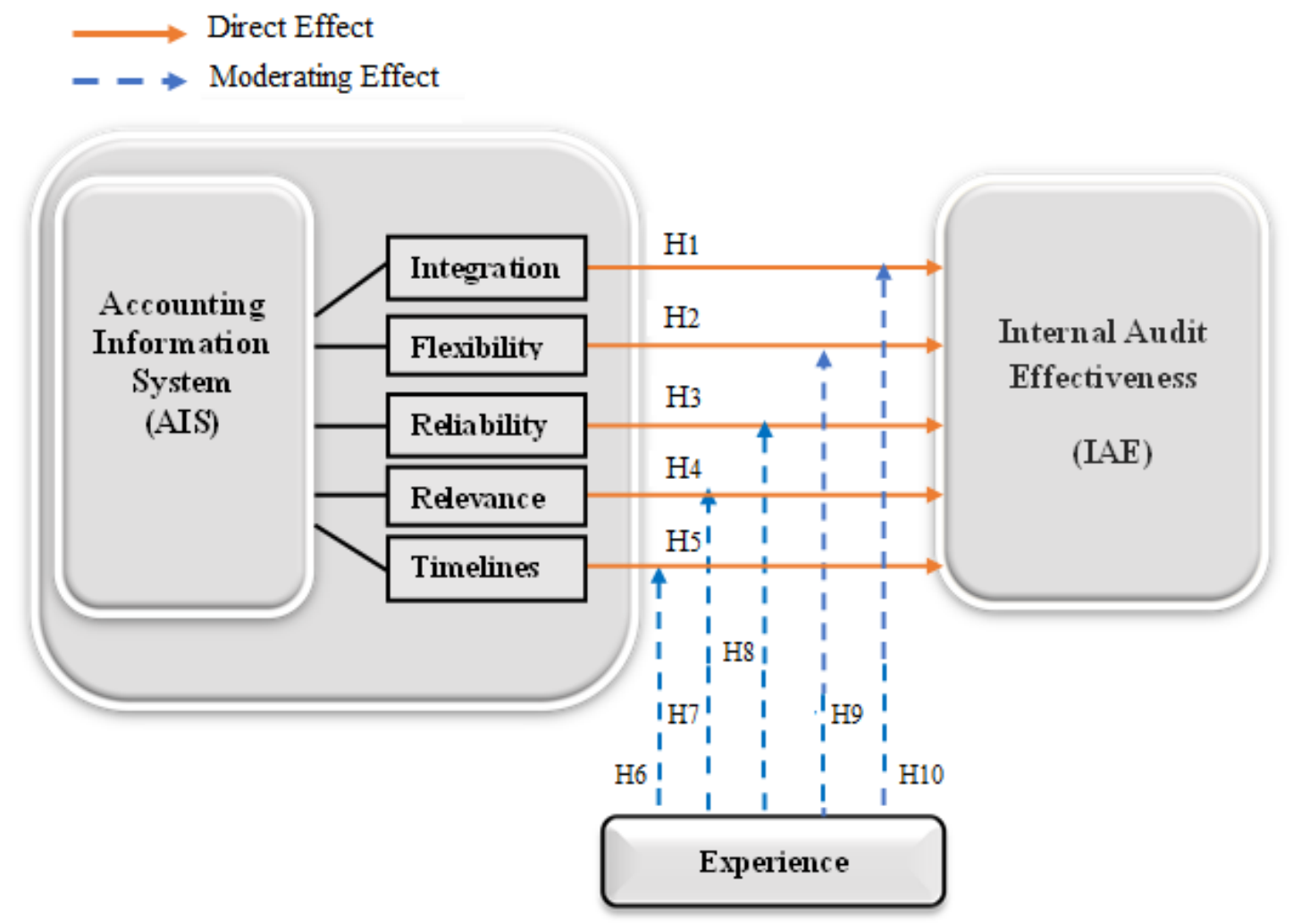

Figure 1: Conceptual Model developed:

Based on the conceptual model in Figure 1, the following hypotheses used are

\section{Direct Hypotheses}

$\mathrm{H}_{1}$ : There is significant effect of integration on IAE

$\mathrm{H}_{2}$ : There is significant impact of Flexibility on IAE

$\mathrm{H}_{3}$ : There is significant impact of reliability on IAE

$\mathrm{H}_{4}$ : There is significant impact of relevance on IAE

$\mathrm{H}_{5}$ : There is significant impact of timeliness on IAE

\section{Moderating Hypotheses}

$\mathrm{H}_{6}$ : Experience moderates the effect of timelines on the IAE

$\mathrm{H}_{7}$ : Experience moderates the effect of relevance on the IAE

$\mathrm{H}_{8}$ : Experience moderates the effect of reliability on the IAE

$\mathrm{H}_{9}$ : Experience moderates the effect of flexibility on the IAE

$\mathrm{H}_{10}$ : Experience moderates the effect of integration on the IAE

\section{METHODOLOGY}

A questionnaire was used for data collection (refer to Appendix A). Each independent variable comprised of 10 items and the dependent variable comprised of 10 items too, while the moderated variable comprised of 8 items. The items of all constructs were developed 
based on previous studies in the same field. The sources of measurement of all items were introduced (refer to Appendix B). The questionnaires were distributed to the respondents (accountants, internal auditors, managers) in 120 companies at the Iraqi stock exchange. The preliminary questionnaire was subjected to a pilot study and experts' judgments to reach the final questionnaire. The questionnaires were distributed by hand to the respondents to avoid any ambiguity in the questions and to avoid any delay. The whole process of distributing the questionnaire and collecting the responses took around 2 months. Sampling was based on the simple random sampling technique. The number of survey questionnaires distributed was 400 questionnaires however, only a total of 375 questionnaires were returned. The valid responses that were used in the analysis process were 365 , resulting in a response rate of $91 \%$. SPSS was used to analyze the data collected. The items of all constructs were coded to facilitate the data analysis. The first stage of analysis was to explore the respondents' demographic information. Descriptive statistics such as mean and standard deviation were used to analyze the data. Reliability tests were conducted including Cronbach's Alpha for internal consistency and Kaiser-Meyer-Olkin and Bartlett's test for checking the adequacy of the data for the next analysis such as exploratory factor analysis (EFA). AMOS was utilized for data analysis on a total of 365 responses to develop the structural equation model (SEM).

\section{RESULT AND DISCUSSIONS}

\section{Demographic Information}

Table 1: Respondents' Educational Achievement

\begin{tabular}{cccc}
\hline Educational Achievement & Frequency & Percent \% & Valid Percent \% \\
\hline High School and & 85 & 23.28 & 23.28 \\
Vocational Education & 70 & 19.17 & 19.17 \\
Diploma & 150 & 41.09 & 41.09 \\
Bachelor & 12 & 3.28 & 3.28 \\
High Diploma & 30 & 8.21 & 8.21 \\
Master & 18 & 4.93 & 4.93 \\
PhD & 365 & 100.00 & 100.00 \\
\hline Total & & &
\end{tabular}

Table 1 illustrates that a large percentage of respondents $(41.09 \%)$ have bachelor degrees, and followed by high school and vocational education certificates $(23.28 \%)$. The less percentage of respondents has a high diploma (4.93\%).

Table 2: Respondents' Occupation

\begin{tabular}{cccc}
\hline Respondents' Occupation & Frequency & Percent \% & Valid Percent \% \\
\hline Accountant & 175 & 47.94 & 47.94 \\
Auditor & 85 & 23.28 & 23.28 \\
Account Manager & 60 & 16.43 & 16.43 \\
Audit Manager & 45 & 12.32 & 12.32 \\
\hline Total & 365 & 100.00 & 100.00 \\
\hline
\end{tabular}


Table 2 demonstrates that the accountants represent the large percentage of respondents $(47.94 \%)$, and followed by the auditors $(23.28 \%)$. The audit managers represent less percentage of respondents $(12.32 \%)$. Generally, the managers represent a good percentage of $28 \%(16.43 \%+12.32 \%)$ which could contribute to the research findings.

Table 3: Respondents' Experience

\begin{tabular}{lccc}
\hline Respondents' Experience & Frequency & Percent $\%$ & Valid Percent \% \\
\hline 3-5 years & 70 & 19.17 & 19.17 \\
6-10 years & 80 & 21.19 & 21.19 \\
11-20 years & 140 & 38.35 & 38.35 \\
21-30 years & 60 & 16.43 & 16.43 \\
31-40 years & 15 & 4.10 & 4.10 \\
\hline Total & 365 & 100.0 & 100.00 \\
\hline
\end{tabular}

It can be seen from Table 3 that most respondents have 11-20 years of experience, and followed by respondents who have 6-10 years of experience. Fewer respondents have 31-40 years of experience. In total, respondents who have more than 10 years of experience account for $60 \%$ of the sample, with $21.19 \%$ of the respondents have more than 6 years of experience, which could reflect good responses.

\section{Descriptive Statistics of CFA}

The descriptive statistics including the averages of mean and standard deviation of all constructs are introduced in Table 4 with the minimum and maximum levels of them.

Table 4: Mean and Standard Deviation of all Constructs

\begin{tabular}{cccccc}
\hline Construct & $\mathbf{N}$ & Minimum & Maximum & Mean & Std. Deviation \\
\hline Integration & 365 & 1.00 & 5.00 & 2.58 & 1.117 \\
Flexibility & 365 & 1.00 & 5.00 & 3.00 & 1.075 \\
Reliability & 365 & 1.00 & 5.00 & 2.81 & 1.114 \\
Relevance & 365 & 1.00 & 5.00 & 3.01 & 1.092 \\
Timeliness & 365 & 1.00 & 5.00 & 2.98 & 1.280 \\
Internal Audit & 365 & 1.00 & 5.00 & 2.95 & 1.026 \\
Effectiveness & 365 & 1.00 & 5.00 & 2.39 & 1.270 \\
Experience & & & &
\end{tabular}

In general, the items of all terms show high percentages of agree, strongly agree, and neutral, which indicates positive trends against most items of all constructs. Moreover, the means of all constructs items range between 2.39 and 3.01, and the standard deviations range between 1.026 and 1.280. This indicates that the data are convergent, consistent, and confirm 
the relationship of the mean to the rest of the data. This can lead to obtaining reliable results of the questionnaire content analysis.

\section{Reliability Test}

The Cronbach Alpha values of all constructs are introduced in Table 5.

Table 5: Reliability Test of All Constructs

\begin{tabular}{cccc}
\hline No & Construct & Number of Items & Alpha Value \\
\hline 1 & Integration & 10 & 0.976 \\
2 & Flexibility & 10 & 0.986 \\
3 & Reliability & 10 & 0.981 \\
4 & Relevance & 10 & 0.985 \\
5 & Timeliness & 10 & 0.951 \\
6 & Internal Audit Effectiveness & 10 & 0.977 \\
7 & Experience & 8 & 0.943 \\
\hline
\end{tabular}

It can be seen from Table 5 that all constructs achieve high Cronbach Alpha values (greater than 0.7). These values mean that there is a high degree of internal stability of all constructs. The high values mean that we can rely on these constructs in achieving the objectives of the study and in the analysis of the results.

\section{Inter-Item Correlation}

The item-test correlation should be at least 0.2. Low item-test correlation means that the content of the item needs to be revised or the item should be removed from the test (Aller et al., 2013). The KMO and Bartlett test is introduced in Table 6.

Table 6: KMO and Bartlett's Test of CFA

\begin{tabular}{l|cc}
\hline \multicolumn{2}{c}{ Kaiser-Meyer-Olkin Measure of Sampling Adequacy. } & .928 \\
\hline \multirow{3}{*}{ Bartlett's Test of Sphericity } & Approx. Chi-Square & 35520.698 \\
& Df & 2278 \\
& Sig. & .000 \\
\hline
\end{tabular}

Legend, $\mathrm{df}=$ degree of freedom, Sig.= significance

Table 6 indicates that KMO and Bartlett's results are within the acceptable limits, where KMO is more than 0.5 and Bartlett's test is less than 0.05 . This reveals that the data is adequate for further analysis. 


\section{DEVELOPMENT OF STRUCTURAL EQUATION MODEL}

\section{Measurement Model}

This study demonstrates the development of the measurement model of the relation between AIS and IAE with the experience as a moderator. Several tests are conducted to analyze the data and test its reliability followed by the EFA to reduce the study variables. Some of the items of some constructs are deleted because they did not fit in the model well and 59 remaining items are distributed across the seven constructs. The goodness of fit reveals the validity of the final measurement model, which indicates the readiness for developing the structural equation model (SEM).

\section{Model Validity}

The final measurement should be measured for validity to develop the structural model. Construct validity is usually used for validity measurement. To measure the model validity, this study uses the construct validity that includes convergent validity and discriminant validity.

\section{Convergent Validity}

In this research, $\mathrm{AVE}$ and $\mathrm{CR}$ are used to measure the convergent validity. AVE is the average amount of variance in observed variables that a latent construct is able to explain (Farrell, 2010). AVE should be equal to 0.50 and above (Hair et al., 2011). Table 7 shows average variance extracted (AVE) and composite reliability (CR).

Table 7: Convergent Validity Results

\begin{tabular}{ccc}
\hline Constructs & Composite Reliability (CR) & Average Variance Extracted (AVE) \\
\hline Integration & 0.884 & 0.677 \\
Flexibility & 0.835 & 0.605 \\
Reliability & 0.832 & 0.599 \\
Relevance & 0.828 & 0.557 \\
Timeliness & 0.821 & 0.520 \\
Internal Audit Effectiveness & 0.873 & 0.666 \\
Experience & 0.824 & 0.504 \\
\hline Rule of Thumb & $>0.7$ & $\geq 0.5$ \\
\hline
\end{tabular}

Table 7 shows that all constructs have values of AVE $\geq 0.5$ and composite reliability of all constructs is also higher than 0.70 , which fits the acceptable values and proves that the convergent validity is achieved through the correlations between the items of each construct. 


\section{Discriminant Validity}

The discriminant validity is attained when there is no correlation between two different dimensions. The discriminant validity can be estimated by AVE-SV test. This test compares the average variance extracted value (AVE) and the share variance (SV) between dimensions (Henseler et al., 2015). The discriminant validity of all constructs is shown in Table 8.

Table 8: Constructs Discriminant Validity

\begin{tabular}{|c|c|c|c|c|c|c|c|}
\hline & INT & FLEX & REL & RELE & TIME & IAE & EXP \\
\hline Integration & 0.710 & & & & & & \\
\hline Flexibility & 0.024 & 0.735 & & & & & \\
\hline Reliability & 0.002 & 0.576 & 0.707 & & & & \\
\hline Relevance & 0.700 & 0.008 & 0.055 & 0.707 & & & \\
\hline Timeliness & 0.560 & -0.043 & -0.004 & 0.506 & 0.778 & & \\
\hline $\begin{array}{l}\text { Internal Audit } \\
\text { Effectiveness }\end{array}$ & 0.707 & -0.008 & 0.022 & 0.706 & 0.752 & 0.746 & \\
\hline Experience & 0.702 & -0.058 & -0.012 & 0.704 & 0.587 & 0.701 & 0.816 \\
\hline
\end{tabular}

In Table 8, the off diagonal values represent the variance shared and diagonal values represent the square root of AVE. The AVE square root values are greater than the variance shared between two constructs indicating high discriminant validity.

\section{STRUCTURAL EQUATION MODEL EVALUATION}

The structural equation model is developed firstly without the moderator to show the direct effect of AIS characteristics on the IAE, and tested for goodness of fit indices (see Figure 2). Then, the model is developed considering the moderating effect. 


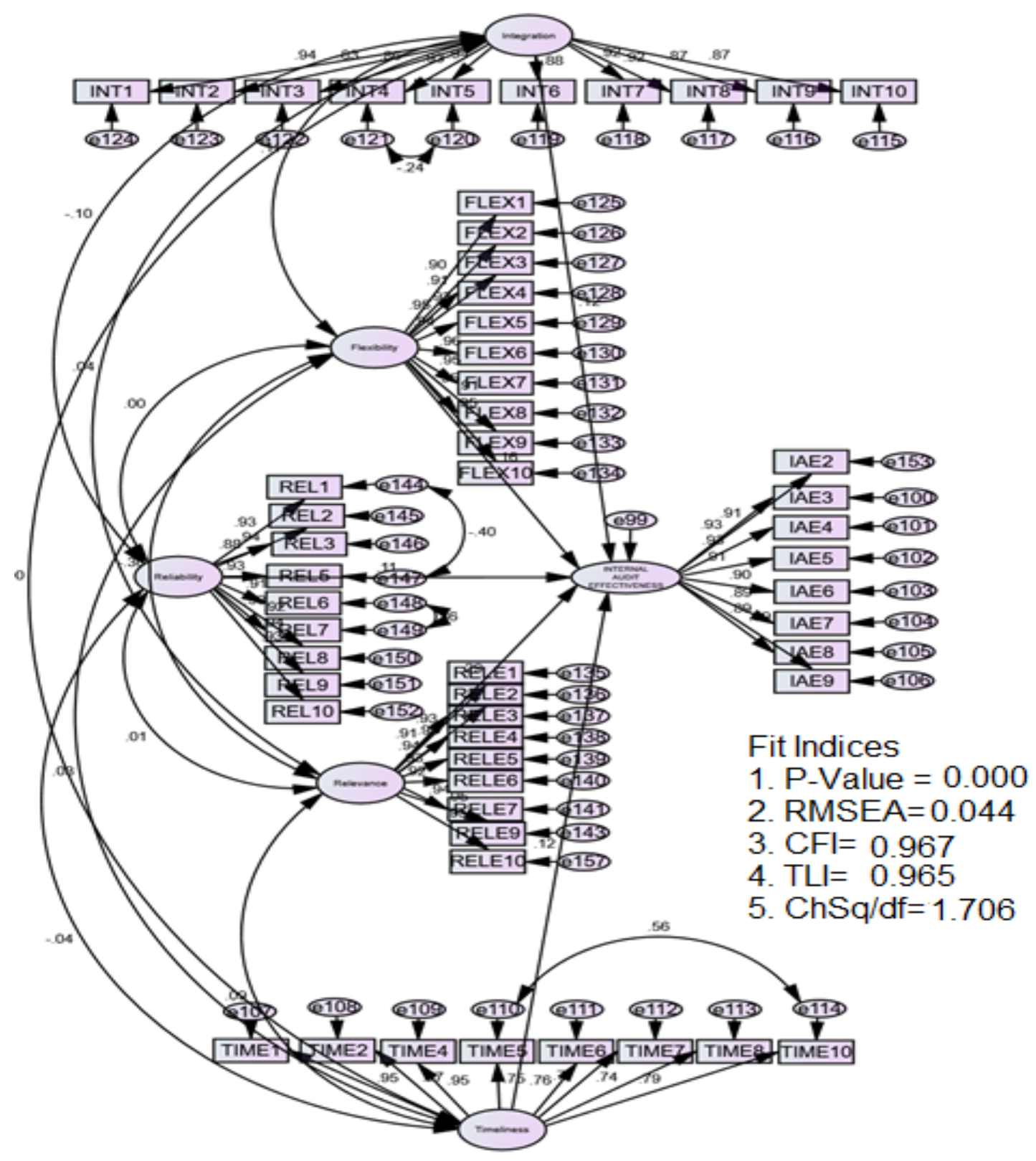

INT=Integration; FLEX=Flexibility; REL=Reliability; RELE= Relevance; TIME=Timeliness; IAE= Internal Audit Effectiveness; EXP= Experience

Figure 2: Structural equation model without moderator

The structural equation model (SEM) without the moderator is tested to determine the model fit using the same indices used in the case of the measurement model. The goodness of fit of the SEM is introduced in Table 9. As shown in Table 9, all the obtained indices values of all constructs fall within the acceptable values. This indicates that the model fits closely the data and ensures the structural model adequacy. 
Table 9: Goodness of Fit of the Structural Equation Model

\begin{tabular}{cccc}
\hline Fit index & Modified Model & Recommended values & Source \\
\hline$\chi^{2} / \mathrm{df}$ & 1.706 & $\leq 5.00$ & Hooper et al. $(2008)$ \\
GFI & 0.920 & $\geq 0.90$ & Hooper et al. $(2008)$ \\
AGFI & 0.914 & $\geq 0.90$ & Hooper et al. $(2008)$ \\
CFI & 0.967 & $\geq 0.90$ & Hooper et al. $(2008)$ \\
IFI & 0.967 & $\geq 0.90$ & Hooper et al. $(2008)$ \\
TLI & 0.965 & $\geq 0.90$ & Hair et al. $(2006)$
\end{tabular}

RMSEA $\quad 0.044 \quad \leq 0.10 \quad$ Hooper et al. (2008), Hair et al. (2010)

$\chi 2 / \mathrm{df}=$ normed chi-square, $\mathrm{GFI}=$ comparative fit index, $\mathrm{AGFI}=$ adjusted goodness-of-fit statistic, $\mathrm{CFI}=$ comparative fit index, $\mathrm{IFI}=$ Incremental fit indices, TLI= Tucker-Lewis, Index, RMSEA $=$ root mean square error.

The structural equation model with moderator is introduced in Figure 3. The model is used to show the effect of the experience on the relation between AIS and IAE. Each indicator of an AIS construct is multiplied by each indicator of the moderating variable leading to produce indicators for a latent interaction term. The statistical significance of the moderating effect is tested by a bootstrapping procedure. Therefore, the experience indicators are multiplied with the AIS and IAE indicators to create a new interaction term called experience *(AIS) including INAC- EXP-INT, INAC- EXP-REL, INAC- EXP-RELE, INAC- EXP-FLEX, INAC- EXP-TIME. The new paths are tested to determine the significance of the interaction effect.

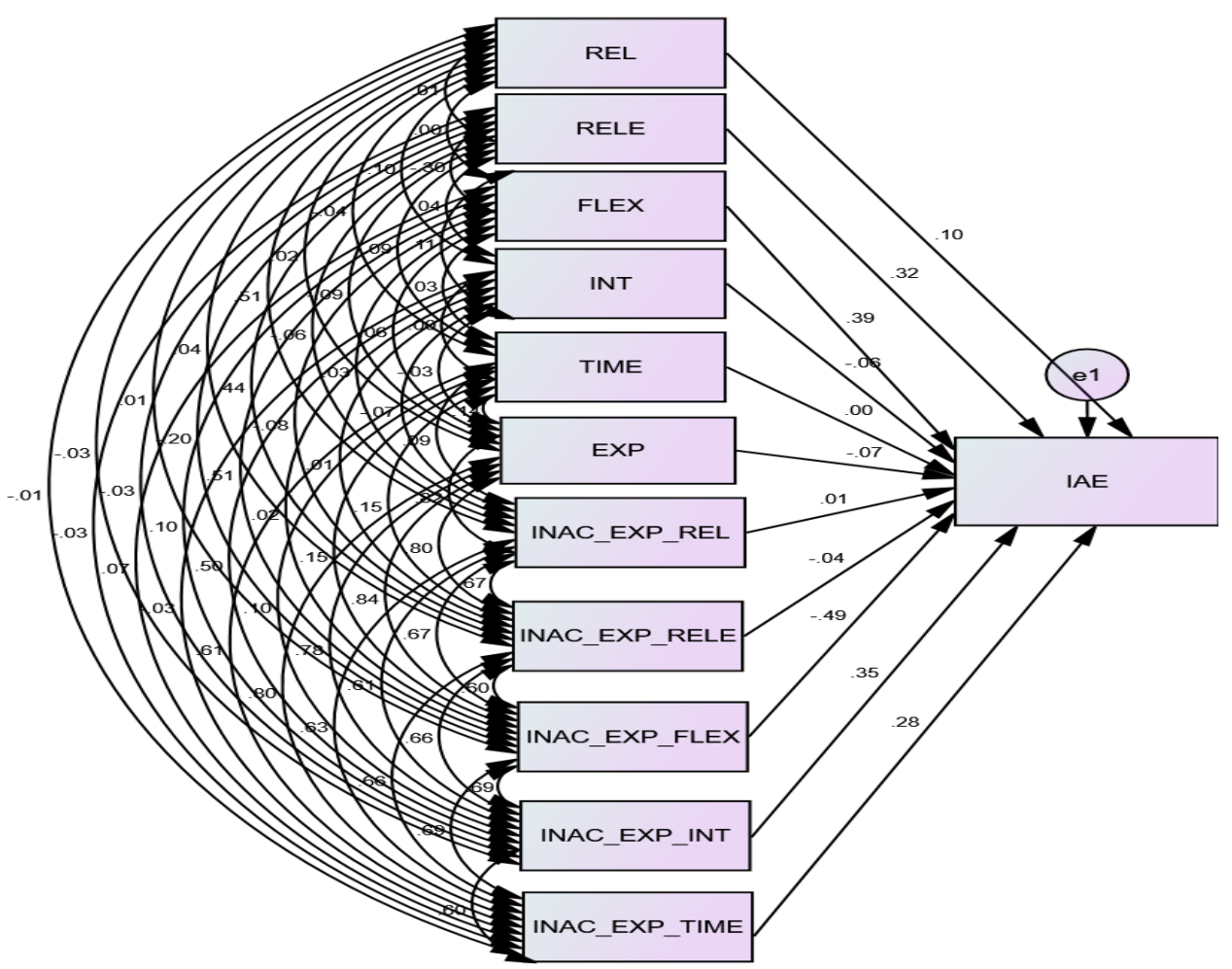

INT=integration; FLEX=flexibility; REL=reliability; RELE=relevance; TIME=timeliness; IAE=internal audit effectiveness; INAC $=$ interaction

Figure 3: Structural equation model with moderator 


\section{HYPOTHESES TESTING}

Hypothesis testing is a method to test if a hypothesis is probable to be true. The hypothesized relations between constructs were put in null hypotheses, which presume true.

\section{Regression Weights of Direct Hypotheses}

The regression analysis is used to test the direct hypotheses effect.

Table 10: Regression Weights of Direct Hypotheses

\begin{tabular}{|c|c|c|c|c|c|c|c|}
\hline Hypothesis & & Relatio & & Estimate & St. Error & C.R. & $\mathbf{P}$ \\
\hline $\mathrm{H} 1$ & IAE & $<---$ & INT & .109 & .048 & 2.287 & .022 \\
\hline $\mathrm{H} 2$ & IAE & $<---$ & FLEX & .150 & .050 & 2.979 & .003 \\
\hline H3 & IAE & $<---$ & REL & .098 & .046 & 2.123 & .034 \\
\hline $\mathrm{H} 4$ & IAE & $<---$ & RELE & .273 & .050 & 5.453 & $* * *$ \\
\hline H5 & IAE & $<---$ & TIME & .095 & .039 & 2.429 & .015 \\
\hline
\end{tabular}

Table 10 indicates all estimates for independent variables are positive and their $\mathrm{p}$ values which are less than 0.05 shows that these relationships are significant. This means that five constructs of AIS have significant effects on the IAE. This confirms the validity of the first five direct hypotheses between the constructs integration, flexibility, reliability, relevance, timeliness, and the IAE that tested by the correlation analysis. It can be seen that all the direct hypotheses are supported. The regression analysis is used to test the direct hypotheses effect.

\section{Regression Weights of Moderating Effect Hypotheses}

For testing the moderation effect, interaction terms were generated using the imputation function in AMOS and then the data was imported from SPSS and run. The regression analysis is used to test the moderating hypotheses. The regression weights with the experience (moderator) are shown in Table 11.

This relation is tested by hypothesis $\mathrm{H}_{6}$, which hypothesizes that experience moderates the effect of timeliness on the IAE. As shown in Table 11, the path coefficient of INAC_EXP_TIME on IAE is 0.058, which indicates that the increase in the interaction of EXP_TIME by one unit leads to an increase in IAE by 0.058 . This estimate has a small standard error (SE) of 0.030 , and a critical ratio (CR), 1.929 is above zero. The probability $(P)$ of getting this ratio is 0.054 , which is more than 0.05 indicating that the regression weight for the interaction of EXP_TIME in predicting the IAE is insignificant. This means that the experience does not moderate the effect of timeliness on the IAE. Thus, the proposed hypothesis is rejected. 
Table 11: Regression Weights with Moderator

\begin{tabular}{|c|c|c|c|c|c|c|c|}
\hline Hypothesis & & & Relation & Estimate & St. Error. & C.R. & $\mathbf{P}$ \\
\hline H6 & IAE & $<---$ & INAC_EXP_TIME & .058 & .030 & 1.929 & .054 \\
\hline $\mathrm{H} 7$ & IAE & $<---$ & INAC_EXP_RELE & -.009 & .036 & -.246 & .805 \\
\hline $\mathrm{H} 8$ & IAE & $<---$ & INAC_EXP_REL & .002 & .036 & .063 & .950 \\
\hline H9 & IAE & $<---$ & INAC_EXP_FLEX & .111 & .038 & -2.894 & .004 \\
\hline H10 & IAE & $<---$ & INAC_EXP_INT & .094 & .039 & 2.426 & .015 \\
\hline
\end{tabular}

$\mathrm{INT}=$ integration, FLEX=flexibility, REL=reliability, RELE=relevance, TIME=timeliness, IAE=internal audit effectiveness, $\mathrm{CR}=$ critical ratio, $\mathrm{p}=$ probability of getting $\mathrm{CR}$, INAC=interaction.

$\mathrm{H}_{7}$ hypothesizes that experience moderates the effect of relevance on the IAE. As shown in Table 11, the path coefficient of INAC_EXP RELE on IAE is -0.009, which indicates that the increase in the interaction of EXP_TIME by one unit leads to a decrease in IAE by -0.009 . This estimate has a small $\mathrm{SE}$ of 0.036 , and a $\mathrm{CR}=-0.246$ is below zero. The $P$ of getting this ratio is 0.805 , which is more than 0.05 indicating that the regression weight for the interaction of EXP_RELE in predicting the IAE is insignificant. This means that the experience does not moderate the effect of relevance on the IAE. Thus, the proposed hypothesis is rejected.

$\mathrm{H}_{8}$ hypothesizes that experience moderate the effect of reliability on the IAE. As shown in Table 11, the path coefficient of INAC_EXP_ REL on IAE is 0.002, which indicates that the increase in the interaction of EXP_ REL by one unit leads to an increase in IAE by 0.002 . This estimate has a small SE of $0.03 \overline{6}$, and a $\mathrm{CR}=0.063$ is above zero. The $P$ of getting this ratio is 0.950 , which is more than 0.05 indicating that the regression weight for the interaction of EXP_REL in predicting the IAE is insignificant. This means that the experience does not moderate the effect of reliability on the IAE. Thus, the proposed hypothesis is rejected.

$\mathrm{H}_{9}$ hypothesizes that experience moderate the effect of flexibility on the IAE. As shown in Table 11, the path coefficient of INAC_EXP_ FLEX on IAE is 0.111, which indicates that the increase in the interaction of EXP_ FLEX by one unit leads to an increase in IAE by 0.111 . This estimate has a small SE of 0.038 , and a $\mathrm{CR}=-2.894$ is below zero. The $P$ of getting this ratio is 0.004 , which is less than 0.05 indicating that the regression weight for the interaction of EXP_ FLEX in predicting the IAE is significant. This means that the experience moderates the effect of flexibility on the IAE. Thus, the proposed hypothesis is supported. Experience helps accountants to understand well all the AIS functions and tasks, thus they will be able to increase the AIS flexibility to adapt to any updates or changes. The experience also increases the ability of auditors to monitor and follow up the implementation of plans and policies and to avoid risks and errors in advance based on reliable and accurate accounting information.

$\mathrm{H}_{10}$ hypothesizes that experience moderates the effect of integration on the IAE. As shown in Table 11, the path coefficient of INAC_EXP_ INT on IAE is 0.094, which indicates that the increase in the interaction of EXP_ INT by one unit leads to an increase in IAE by 0.094 . This estimate has a small SE of 0.039 , and a $\mathrm{CR}=2.426$ is above zero. The $P$ of getting this ratio is 0.015 , which is less than 0.05 indicating that the regression weight for the 
interaction of EXP_INT in predicting the IAE is significant. This means that the experience moderates the effect of integration on the IAE. Thus, the proposed hypothesis is supported. The experience of accountants and auditors enhances the integration between all functions of AIS and IA and with other information systems in the organizations, which helps to provide reliable and accurate financial information, and consequently increases the effectiveness of the of planning, implementation and control tasks so as to provide all the information needed by the decision-makers.

The summary of all hypotheses including the direct hypotheses and the moderating hypotheses is introduced in Table 12.

Table 12: Summary of Research Hypotheses

\begin{tabular}{|c|c|c|}
\hline No. & Hypothesis & Result \\
\hline 1 & $\mathrm{H} 1$ : there is a significant effect of integration on IAE & Fail to reject \\
\hline 2 & $\mathrm{H} 2$ : there is a significant effect of Flexibility on IAE & Fail to reject \\
\hline 3 & H3: there is a significant effect of reliability on IAE & Fail to reject \\
\hline 4 & H4: there is a significant effect of relevance on IAE & Fail to reject \\
\hline 5 & H5: there is a significant effect of timeliness on IAE & Fail to reject \\
\hline 6 & H6: experience does moderate the effect of timelines on the IAE & Rejected \\
\hline 7 & H7: experience does moderate the effect of relevance on the IAE & Rejected \\
\hline 8 & $\mathrm{H} 8$ : experience does moderate the effect of reliability on the IAE & Rejected \\
\hline 9 & H9: experience does moderate the effect of flexibility on the IAE & Fail to reject \\
\hline 10 & $\mathrm{H}_{10}$ : experience does moderate the effect of integration on the IAE & Fail to reject \\
\hline
\end{tabular}

\section{CONCLUSION}

AIS and its characteristics are important to improve the IAE. This study contributes to the literature by testing the moderating effect of experience, which is a new variable in accounting studies. Consequently, this study demonstrates the development of a structural equation model of the relation between AIS and IAE with the experience as a moderator. Several tests and analyses were conducted to test the normality and reliability of the data for further analysis such as confirmatory factor analysis and structural equation model development. The development of the measurement was demonstrated. This model was tested for validity to come out with the structural equation model (SEM) using the confirmatory factor analysis. Both measurement and structural equation model were validated using various measures of goodness of fit. The regression analysis was used to test the direct hypotheses effect and the moderating effect of experience. All the direct hypotheses are supported, which confirm the significant effect of the AIS quality characteristics on the IAE. Regarding the moderating hypotheses, the experience only moderates the relations between integration and flexibility characteristics and the IAE. On the other hand, the moderated effect of experience on the timeliness, reliability and relevance were not supported. The SEM model confirmed the effect of AIS on enhancing the audit process and assisting management in making the right decisions. Moreover, the model confirmed the role of experience in improving the accounting, and auditing reports, consequently, enhances management 
decision making. Governments can benefit from this study because better internal audit performance of companies will lead to better GDP and high income of citizens. The study offers a foundation for the researchers to do more researches on the role of experience on AIS and IAE and their relation.

\section{REFERENCES}

Abbas, Q., \& Iqbal, J. (2012). Internal Control System: Analyzing Theoretical Perspective and Practices. Middle-East Journal of Scientific Research, 12(4), 530-538.

Abdallah, A. A. J. (2014). The impact of using accounting information systems on the quality of financial statements submitted to the income and sales tax department In Jordan. European Scientific Journal, ESJ, 9(10).

Adams, M. B. (1994). Agency theory and the internal audit. Managerial Auditing Journal, 9(8), 8-12.

Aller, M. B., Vargas, I., Garcia, I., Coderch, J., Colomés, L., Llopart, J. R., \& Vázquez, M. L. (2013). A tool for assessing continuity of care across care levels: an extended psychometric validation of the CCAENA questionnaire. International Journal of Integrated Care, 13(4).

Almaliki, O. J., Rapani, N. H. A., \& Khalid, A. A. (2018). The Effect of Accounting Information System on Internal Audit Effectiveness; Testing the Moderating Role of Experience. Journal of Advanced Research in Dynamical \& Control Systems, 10(10), 65-75.

Al-Qudah \& Ahmed G.M. (2011).in a study entitled: The Impact of Accounting Information System on Effectiveness of Internal Control in Jordan Commercial Bank "Field Study", stated that AIS has an influence on the effectiveness of internal control.

Alshanti, A.M.(2013) .The impact of applying accounting information systems to improve the effectiveness and efficiency of internal auditing in the Jordanian industrial sector, the Islamic University Journal of Economic and Administrative Studies, 21(I)

Altawalbeh, M. A. F., Na'el Rawhi Hashem, F., \& Alduneibat, K. A. A. (2017). The Role of Accounting Information Systems in Activating the Role of the Responsibility in the Jordanian Industrial Companies. Journal of Modern Accounting and Auditing, 13(1), 1-7.

Alzeban, A., \& Gwilliam, D. (2014). Factors affecting the internal audit effectiveness: A survey of the Saudi public sector. Journal of International Accounting, Auditing and Taxation, 23(2), 7486.

Arena, M. and Azzone, G. (2009), Identifying organizational drivers of internal audit effectiveness, International Journal of Auditing, Vol. 13 No. 1, pp. 43-60.

Bazley, M., Hancock, P., \& Robinson, P. (2014). Contemporary Accounting PDF. Cengage Learning Australia.

Bukenya, M. (2014). Quality of accounting information and financial performance of the public sector in Uganda. American Journal of Research Communication, 2(25), 183-203.

Changwony, M. K., \& Rotich, G. (2015). Role of internal audit function in promoting effective corporate governance of commercial banks in Kenya. International Journal of Business \& Law Research, 3(1), 15-33.

Chenhall, R. H., \& Morris, D. (1986). The impact of structure, environment, and interdependence on the perceived usefulness of management accounting systems. Accounting Review, 16-35.

Classen, N., Van Gils, A., Bammens, Y., \& Carree, M. (2012). Accessing Resources from Innovation Partners: The Search Breadth of Family SMEs. Journal of Small Business Management, 50(2), 191-215.

ISSN 19852126 
Datta, S., \& Iskandar-Datta, M. (2014). Upper-echelon executive human capital and compensation: Generalist vs specialist skills. Strategic Management Journal, 35(12), 1853-1866.

Farrell, A. M. (2010). Insufficient discriminant validity: A comment on Bove, Pervan, Beatty. Journal of Business Research, 63(3), 324-327.

Hair, J. F., Black, W. C., Babin, B. J., Anderson, R. E., \& Latham, R. (2010).Multivariate data analysis (7thed). New Jersey: Pearson.

Hair, J. F., Black, W. C., Babin, B. J., Anderson, R. E., \& Tatham, R. L. (2006a). Multivariate data analysis (Vol. 6): Pearson Prentice Hall Upper Saddle River, NJ.

Hair, J. F., Ringle, C. M., \& Sarstedt, M. (2011). PLS-SEM: Indeed a silver bullet. Journal of Marketing theory and Practice, 19(2), 139-152.

Henseler, J., Ringle, C. M., \& Sarstedt, M. (2015). A new criterion for assessing discriminant validity in variance-based structural equation modeling. Journal of the academy of marketing science, 43(1), 115-135.

Herda, D. N., \& Martin, K. A. (2016). The effects of auditor experience and professional commitment on acceptance of underreporting time: A moderated mediation analysis. Current Issues in Auditing, 10(2), A14-A27.

Hiedmann, M., Schäffer, U., \& Strahringer. (2008). Exploring the Role of Management Accounting Sistems in Strategic Sensemaking. Information Sistems Management,25(3) 244-257.

Hooper, D., Coughlan, J., \& Mullen, M. (2008). Structural equation modelling: Guidelines for determining model fit. Articles, 2.

Hussien, K. S. (2005). The Impact of accounting Information Systems on the effectiveness of internal auditing systems of the application on public shareholding companies in Sudan .Khartoum: University of Science and Technology, Unpublished Masters Thesis.

Jones, F. L., \& Rama, D. V. (2003). Accounting information systems: a business process approach. Thomson/South-Western

kh Al-Dalabeeh, A. E. R., \& Al-Zeaud, H. A. (2012). Accounting information systems and their role in the measurement and cost thrifting in public shareholding industrial companies in Jordan. International Journal of Business and Management, 7(12), 97.

Laudon, K. C., \& Laudon, J. P. (2004). Management information systems: Managing the digital firm. New Jersey, 8.

McGilvray, D. (2008). Executing data quality projects: Ten steps to quality data and Trusted Information(TM).Elsevier.

Mihret, D. G., \& Yismaw, A. W. (2007). Internal audit effectiveness: An Ethiopian public sector case study. Managerial Auditing Journal, 22(5), 470-484.

Moorthy, M. K., Mohamed, A. S. Z., Gopalan, M., \& San, L. H. (2011). The impact of information technology on internal auditing. African Journal of Business Management.

Napitupulu, I. H., Mahyuni, S., \& Sibarani, J. L. (2016). The impact of internal control effectiveness to the quality of management accounting information system: The survey on State-Owned Enterprises (SOEs). Journal of Theoretical and Applied Information Technology, 88(2), 358366.

Neogy, T. K. (2014). Evaluation of Efficiency of Accounting Information Systems: A Study on Mobile Telecommunication Companies in Bangladesh. Global Disclosure of Economics and Business, 3(1), 40-58. 
Nicolaou, A. I. (2000). A contingency model of perceived effectiveness in accounting information systems: Organizational coordination and control effects. International Journal of Accounting Information Systems, 1(2), 91-105.

Ong, C. S., Day, M. Y., \& Hsu, W. L. (2009). The measurement of user satisfaction with question answering systems. Information and Management, 46(7), 397-403.

Patel, S. B. P. (2015). Effects of accounting information system on Organizational Profitability. IJRAR- International Journal of Research and Analytical Reviews, 2(1), 72-76.

Peursem, K. V. \& Pumphrey, L. D. (2005), “Internal Auditors and Independence: An Agency Lens on Corporate Practice", Financial Reporting, Regulation and Governance , 4(2), 1-33.

Qatanani, K. M., \& Hezabr, A. A. (2015). The effect of using accounting information systems to improve the value chain in business organizations-empirical study. European Journal of Accounting Auditing and Finance Research, 3(6), 1-11.

Romney, M. B., Steinbart, P. (2009). Accounting Information Systems. 11th Ed. Pearson.

Saatcioglu, O. Y., Ozmen, O. N. T., \& Eriş, E. D. (2012). A study on knowledge management and firm performance in Turkish IT sector. International Journal of Logistics Systems and Management, 11(2), 213.

Shagari, S. L., Abdullah, A., \& Saat, R. M. (2017). Contributory Factors of Accounting Information Systems Effectiveness in Nigerian Banking Sector. Asian Journal of Multidisciplinary Studies, 151.

Soudani, S. N. (2013). The Impact of Implementation of E-Accounting System on Financial Performance with Effects of Internal Control Systems. Research Journal of Finance and Accounting, 4(11), 17-28.

Sri Mulyani NS.( 2009). Sistem Informasi Manajemen (Rumah Sakit : Analisis dan Perancangan). Cetakan ke-I. Bandung: Abdi Sistematika

Tan, Ö. F. (2016). Impact of Accounting Information Systems On Internal Auditors In Turkey. Marmara Üniversitesi Öneri Dergisi @BULLET Cilt, 12(46), 1300-845.

Teru, S. P., Idoku, I., \& Ndeyati, J. T. (2017). A Review of the Impact of Accounting Information System for Effective Internal Control on Firm Performance. Indian Journal of Finance and Banking, 1(2), 52-59.

Toth, Z. (2012). The current role of accounting information systems. Theory, Methodology, Practice, 8(1), 91.

Vasudevan, H., \& Chawan, A. (2014). Demystifying knowledge management in Indian manufacturing SMEs. Procedia Engineering, 97, 1724-1734.

Vera-Munoz, S. C., Kinney Jr, W. R., \& Bonner, S. E. (2001). The effects of domain experience and task presentation format on accountants' information relevance assurance. The Accounting Review, 76(3), 405-429.

von den Driesch, T., da Costa, M. E. S., Flatten, T. C., \& Brettel, M. (2015). How CEO experience, personality, and network affect firms' dynamic capabilities. European Management Journal, $33(4), 245-256$.

Wixom, B. H., \& Todd, P. A. (2005). A theoretical integration of user satisfaction and technology acceptance. Information Systems Research, 16(1), 85-102. 


\section{Appendix A}

\section{Section (A) Background Information (Demographic Factors)}

Please answer the following questions and mark $(\mathrm{X})$ in front of the appropriate answer, please tick one only.

1- What is your age?

Less than 20 years

20-30 years

31-40 years

41-50 years

More than 50 years

2- What is your educational achievement?

High School

Diploma degree

Bachelor degree

$\square \quad$ Master's degree

PhD degree

3- What is your occupation?

Accountants' managers

Accountants

$\square \quad$ Internal auditors

Other: Please specify ( )

4- How long have you been working for this company?

Less than 1 year

1-3 years

3-5 years

5-7 years

More than 7 years, Please specify

Section (B): Research Variables

All the items of research variables are measured using five Likert scale: Please circle the most appropriate statement according to the scale.

(1) Strongly Disagree

(2) Disagree

(3) Neutral

(4) Agree

(5) Strongly Agree

ISSN 19852126 


\section{Independent Variables}

\section{1- Integration}

\begin{tabular}{|c|c|c|c|c|c|c|}
\hline No. & Statement & 1 & 2 & 3 & 4 & 5 \\
\hline 1 & $\begin{array}{l}\text { Software, hardware and networks in my organization are complementing each } \\
\text { other in formal procedures }\end{array}$ & & & & & \\
\hline 2 & All business processes are simple and understandable & & & & & \\
\hline 3 & $\begin{array}{l}\text { Centralized data management improves the accuracy of data and information } \\
\text { management }\end{array}$ & & & & & \\
\hline 4 & The decision-making process is based on an integrated database of AIS & & & & & \\
\hline 5 & $\begin{array}{l}\text { The applied AIS encourages the spirit of creativity and innovation among all } \\
\text { employees }\end{array}$ & & & & & \\
\hline 6 & AIS is integrated with other management information systems & & & & & \\
\hline 7 & The integration of AIS improves the internal audit effectiveness & & & & & \\
\hline 8 & AIS enhance compliance with laws and accounting standards & & & & & \\
\hline 9 & $\begin{array}{l}\text { The AIS includes internal control which reduce the cases of fraud in the } \\
\text { accounting data }\end{array}$ & & & & & \\
\hline 10 & AIS are integrated with other information systems & & & & & \\
\hline
\end{tabular}

\section{2- Flexibility}

\begin{tabular}{|c|c|c|c|c|c|c|}
\hline No. & Statement & 1 & 2 & 3 & 4 & 5 \\
\hline 1 & AIS is useful for all stakeholders as a result of business development & & & & & \\
\hline 2 & AIS provides various options for selection & & & & & \\
\hline 3 & AIS has the ability to adapt to modern legislation and laws & & & & & \\
\hline 4 & AIS has the ability to adapt to accounting standards and their amendments & & & & & \\
\hline 5 & AIS flexibility contributes in improving the organization performance & & & & & \\
\hline 6 & AIS provide a computer-based database system to store and retrieve data & & & & & \\
\hline 7 & AIS provides information capable of correcting previous events & & & & & \\
\hline 8 & The processing speed of the AIS helps in doing work quickly & & & & & \\
\hline 9 & AIS can track all events in an efficient manner & & & & & \\
\hline 10 & The flexibility of AIS affects the internal audit effectiveness & & & & & \\
\hline
\end{tabular}

\section{3- Reliability}

\begin{tabular}{|c|c|c|c|c|c|c|}
\hline No. & Statement & 1 & 2 & 3 & 4 & 5 \\
\hline 1 & Reliability of AIS outputs is important for decision makers & & & & & \\
\hline 2 & The result of AIS are free from error and bias & & & & & \\
\hline 3 & The reliability of AIS system improves the organization performance & & & & & \\
\hline 4 & AIS helps predictability & & & & & \\
\hline 5 & $\begin{array}{l}\text { The information contained in the financial reports issued by the AIS are credible } \\
\text { and transparent }\end{array}$ & & & & & \\
\hline 6 & Management trusts the quality of AIS & & & & & \\
\hline 7 & AIS provides information that reduces errors during work & & & & & \\
\hline 8 & The AIS provides accurate and relevant information & & & & & \\
\hline 9 & The use of AIS enables to manage our tasks effectively & & & & & \\
\hline 10 & The reliability of accounting information affects the internal audit effectiveness & & & & & \\
\hline
\end{tabular}

\section{4- Relevance}

\begin{tabular}{|c|c|c|c|c|c|c|}
\hline No. & Statement & 1 & 2 & 3 & 4 & 5 \\
\hline 1 & AIS provides efficient and relevant information to serve any purpose & & & & & \\
\hline 2 & AIS provides relevant information for decision making & & & & & \\
\hline 3 & $\begin{array}{l}\text { AIS provides operational reports related to the current operations of the } \\
\text { organization }\end{array}$ & & & & & \\
\hline 4 & AIS contributes to make the output information more suitable for decision- & & & & & \\
\hline
\end{tabular}

ISSN 19852126 


\begin{tabular}{|l|l|l|l|l|}
\hline & makers & & & \\
\hline 5 & AIS provides relevant information to achieve organization's goals & & & \\
\hline 6 & AIS provides relevant information supporting organization strategy & & & \\
\hline 7 & AIS provides relevant information to solve problem in hands & & & \\
\hline 8 & $\begin{array}{l}\text { The use of AIS issues periodic reports on all the organization activities for } \\
\text { decision making }\end{array}$ & & & \\
\hline 9 & Relevant Information meets the information need of the consumer & & & \\
\hline 10 & The relevance of AIS affects the internal audit effectiveness & & & \\
\hline
\end{tabular}

\section{5- Timeliness}

\begin{tabular}{|c|c|c|c|c|c|c|}
\hline No. & Statement & 1 & 2 & 3 & 4 & 5 \\
\hline 1 & Requested information is created immediately upon request & & & & & \\
\hline 2 & Information supplied automatically upon processing is completed & & & & & \\
\hline 3 & $\begin{array}{l}\text { Reports are provided frequently on a systematic, regular basis such as daily } \\
\text { reports, weekly reports }\end{array}$ & & & & & \\
\hline 4 & $\begin{array}{l}\text { There is no delay between an event occurred and relevant information being } \\
\text { reported }\end{array}$ & & & & & \\
\hline 5 & Correct and consistence information is provided on time when required & & & & & \\
\hline 6 & Data is available regularly enough to influence management decisions & & & & & \\
\hline 7 & The information from AIS reflects the current state of the world that it represents & & & & & \\
\hline 8 & The use of AIS assists in reducing cost and time & & & & & \\
\hline 9 & The processing speed of the AIS helps in doing work quickly & & & & & \\
\hline 10 & The timeliness of AIS affects the internal audit effectiveness & & & & & \\
\hline
\end{tabular}

\section{Dependent Variable}

\section{Internal Audit Effectiveness}

\begin{tabular}{|c|c|c|c|c|c|c|}
\hline No. & Statement & 1 & 2 & 3 & 4 & 5 \\
\hline 1 & The internal audit improves organization performance & & & & & \\
\hline 2 & $\begin{array}{l}\text { The internal audit reviews operations to ascertain that results are consistent with } \\
\text { organization goals }\end{array}$ & & & & & \\
\hline 3 & $\begin{array}{l}\text { The internal audit determines the adequacy and effectiveness of the internal } \\
\text { accounting and operating controls }\end{array}$ & & & & & \\
\hline 4 & The internal audit reviews the accuracy and reliability of financial reports & & & & & \\
\hline 5 & $\begin{array}{l}\text { The internal audit reviews the compliance with policies, plans, laws and } \\
\text { regulations }\end{array}$ & & & & & \\
\hline 6 & The internal audit improves the effectiveness of risk management & & & & & \\
\hline 7 & The internal audit reviews the economical, and efficient use of resources & & & & & \\
\hline 8 & The internal audit evaluates the internal control system & & & & & \\
\hline 9 & The internal audit improves the organization's productivity & & & & & \\
\hline 10 & The internal audit develops appropriate annual audit plans & & & & & \\
\hline
\end{tabular}

\section{Moderated Variable}

\section{$\underline{\text { Experience }}$}

\begin{tabular}{|c|c|c|c|c|c|c|}
\hline No. & Statement & 1 & 2 & 3 & 4 & s \\
\hline 1 & Experience enables the management to make accurate decision & & & & & \\
\hline 2 & Experience enables the employees to do their task efficiently & & & & & \\
\hline 3 & Experience enhances the internal audit performancele & & & & & \\
\hline 4 & $\begin{array}{l}\text { The performance of the AIS depends on employees professional knowledge and } \\
\text { experience }\end{array}$ & & & & & \\
\hline 5 & $\begin{array}{l}\text { The organization trains the employees to increase their skill and knowledge in } \\
\text { AIS }\end{array}$ & & & & & \\
\hline 6 & The experience help auditors to use software and hardware in AIS in an efficient & & & & & \\
\hline
\end{tabular}

ISSN 19852126 


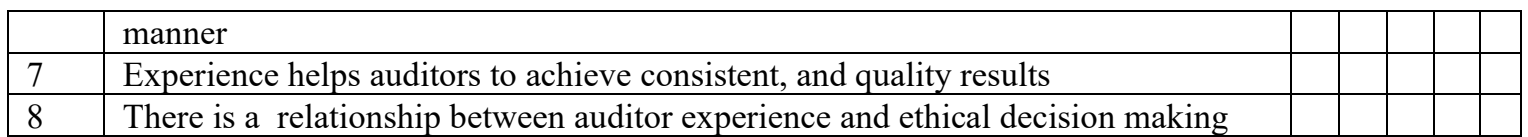

\section{Appendix B}

\section{Source of Constructs Items}

\begin{tabular}{lcl}
\hline Construct & $\begin{array}{c}\text { Number of } \\
\text { Items }\end{array}$ & Sourcesf \\
\hline Integration & 10 & $\begin{array}{l}\text { Chenhall \& Morris (1986); Napitupulu et al. (2016); Tan } \\
(2016) ; \text { Qatanani and Hezabr (2015) }\end{array}$ \\
Flexible & 10 & $\begin{array}{l}\text { Napitupulu et al., (2016); } \\
(2016)\end{array}$ \\
Reliability & 10 & Napitupulu et al. (2016); Shagari et al. (2017) \\
Relevance & 10 & $\begin{array}{l}\text { Teru et al. (2017); kh Al-Dalabeeh and Al-Zeaud (2012); } \\
\text { Abdallah (2014); Shagari et al. (2017) }\end{array}$ \\
Timeliness & 10 & $\begin{array}{l}\text { Chenhall \& Morris (1986); Patel (2015); Shagari et al. } \\
(2017)\end{array}$ \\
Experience & 8 & $\begin{array}{l}\text { Toth (2012); Altawalbeh et al. (2017); Herda and Martin } \\
(2016)\end{array}$ \\
$\begin{array}{l}\text { Internal } \\
\text { Audit } \\
\text { Effectiveness }\end{array}$ & 10 & Alzeban and Gwilliam (2014)
\end{tabular}

